\title{
Sports and Disciplined Movement - Paths to Stimulating Strivings
}

\author{
Deporte y movimiento disciplinado - Caminos bacia \\ esfuerzos estimulantes
}

JESÚS ILUNDÁIN-AGURRUZA

Linfield College (Oregon, Usa)

Artículo recibido: 12 octubre 2015

Solicitud de revisión: 14 enero 2015

Artículo aceptado: 02 febrero 2016

\begin{abstract}
The focus of this article is the relation between life, sport, and disciplined movement. How do these enhance life? This means looking at sports in terms of the qualitative experiences they afford and considering the role of disciplined movement. Phenomenological description helps explore the normative paths that heighten said experiences.At their best, such paths result in skillful strivings to excel within communitarian frameworks, of which the Japanese practices of self-cultivation are exemplary. Sheets-Johnstone's forays into kinesthesia, Ortega y Gasset's meditations, and Husserl's historical lifeworld (lebenswelt) animate this account. The aim is to show how sports and movement, in bridling an exuberant temperament, cultivate our abilities, creativity, and excellence, ultimately encouraging stimulating lives.
\end{abstract}

Keywords: sports, lifeworld, phenomenology, self-cultivation, Japanese dō, skillful fluency

Resumen

El artículo examina la relación entre la vida, los deportes, y el movimiento disciplinado. ¿Cómo mejoran éstos la vida? Esto implica evaluar a los deportes acorde a las experiencias cualitativas que hacen posibles y considerar el papel del movimiento disciplinado. La descripción fenomenológica ayuda a explorar los caminos normativos que mejoran tales experiencias. En los mejores casos, éstos conllevan esfuerzos hábiles de superación dentro de marcos comnunitarios. Las prácticas japonesas de autocultivo destacan a este respecto. Las indagaciones de Sheets-Johnstone sobre la kinestesia, las meditaciones de Ortega y Gasset, y las ideas de Husserl sobre el Lebenswelt histórico animan el análisis. El objetivo es mostrar cómo deportes y movimiento, al embridar un temperamento exuberante, cultivan 
nuestras destrezas, creatividad, y excelencia, fomentando, en ultimo término, vidas estimulantes.

Palabras Clave: deportes, lifeworld, fenomenología, autocultivo, dō japoneses, destreza fluída

Indeed a skittish borse, with its nervous bead and fiery eye, is a splendid image of stirring life

José Ortega y Gasset (1961: 22)

\section{INTRODUCTION}

This inquiry focuses on the relation between life, sports, and disciplined movement. ${ }^{1}$ For the purposes of this examination, 'sport' is discussed in concert with other performative endeavors such as martial arts or dance. Two reasons recommend this. One, their shared cultivation of refined and disciplined movement deepens our understanding of the qualitative facets of animate lives. Two, at certain junctures, this essay's existential and normative concerns benefit from cross-cultural comparison between sport and other practices such as Japanese $d \bar{o}$ (arts of self-cultivation, 道). The guiding question is: how do such endeavors enhance life? Methodologically, this question is both phenomenological tool with which to pry into the qualitative aspects of our moving lives, and mechanism to examine the structure common to sportive and performative experiences and their existential worth.

This means considering the role of disciplined movement. Interestingly, this phenomenological descriptive undertaking opens normative paths that heighten experience. These paths issue from the very nature of sports (and akin performative practices) and our skills; they result in skillful stri-

1 Text based on «Bridled Exuberance: Sport and the Cultivation of an Inspiring Life», presentation delivered in a panel organized by Maxine Sheets-Johnstone, annual meeting of the Society for Phenomenology and Existential Philosophy (SPEP) - University of Oregon, Eugene, October 24-26, 2014. A different version was delivered as a keynote, «Sport and Life: an Inspiring Partnership» at the Japanese Society for the Philosophy of Sport and Physical Education (JSPSPE) - University of Tsukuba, August 19-20, 2014; and, with further changes at the Korean Alliance for Health, Physical Education, Recreation and Dance (KAHPERD) Conference - Incheon Korea,August 20-23, 2014. I am grateful to the audiences for their thoughtful questions and feedback. A fuller account of key ideas herein discussed can be found in Ilundáin-Agurruza 2014a and 2014b. 
vings to excel. Just as Japanese $d \bar{o}$ offer some of the most refined expressions of such paths, masters embody the ways we can perfect our skills. These paragons of performative expertise, instead of coping, as Hubert Dreyfus (2014) posits, perform with skillful fluency and incorporate a $k i$ netic signature. In some cases, rather than being role models, they act as moral exemplars. In the following, Maxine Sheets-Johnstone's writings on kinesthesia and movement, José Ortega y Gasset's 'meditations,' to use his term for phenomenological analyses, and Edmund Husserl's later developments concerning a historical lifeworld breathe life into this account. Concisely, this study examines how sports and disciplined movement-in bridling an exuberant temperament we are well advised to nurture-help cultivate our abilities, creativity, and excellence, ultimately encouraging inspiring lives and stimulating skillful strivings.

\section{SPORTS AND TRUTH}

The phenomenon of sport is a kinetic praxis: intelligence rooted in movement that cultivates a corporeal wisdom. As praxis, it falls under the scope of Aristotelian practical wisdom whereby we act rightly for the present circumstances. It also bespeaks of skill, creativity, and reflection, demanding above all action on our part.Additionally, there is an element of risk, given that our best judgment for a given situation may err. Then all our exertions may come to nothing-or worse, end in injury, even death, in some high-risk activities. This kinetic praxis is a thinking in movement that, Maxine Sheets-Johnstone states, «is a way of being in the world, of wondering or exploring the world, taking it up moment by moment and living it directly in movement, kinetically» (2009: 35). This may lead to gnostic and existential truths.

In contrast to epistemic truths that are reduced to expressing propositional 'verities' and facts of/about the world, the gnostic ones are qualitatively felt to be true (Ilundáin-Agurruza, forthcoming). They resonate within us. Moreover, they have the capacity to transmute into momentous decisions and actions that may change and set a new course for our lives. Redolent of John Dewey's notion of an experience, which marks a before and an after the significant experience (1980:36), these amount to experiential epiphanies. In this way, gnostic truths may act as intellectual compasses, pace Socrates' realization about his own ignorance when confronted by the Delphic oracular judgment that he is the wisest person in Athens, 
or Sheets-Johnstone's insight regarding the centrality of movement and animate life borne from her professional dance experience. They can also become existential revelations of, for instance, our mortality. Simply take big wave surfer Shane Dorian's near death drowning at famed Mavericks' 60-foot plus waves. In the case of sports, such truths become corporeally resonant.

The very structure of sports warrants this, for as Heather Reid (2009) argues, sports are truth-seeking contests. As such, they test our mettle without false comfort when we are found wanting. This means that sports are uniquely constituted to give opportunities for such gnostic, personal, lived truths. Dewey's (1980) example of one such significant experience is a tempest at sea. But whereas for him the tempest is something fortuitous or accidental, in the case of offshore sailing, such encounters with the unpredictably dangerous and its epiphanic possibilities are inherent to the activity (Ilundáin et al. 2012). As Joshua Slocum, the first person to circumnavigate the earth alone said, "Where, after all, would be the poetry of the sea were there no wild waves?» (1956: 192). Sports and some performative practices, by courting such possibilities assiduously bring characteristic and enriching qualitative experiences worth writing poetry and philosophy about. We explore this qualitative facet next.

\section{THE UNIQUE KINETIC, KINESTHETIC AND TACTILE DYNAMICS OF SPORT}

Quality lies at the heart of sports in at least two ways: they afford us qualitative experiences, and the quality of our effort is a variable with existential ramifications, as just intimated. In this section we consider the first one. Sports are a canto to human inventiveness in the face of natural limitations. In terms of sheer physical abilities, humans are the runts of the litter in the animal world. Dolphins make Michael Phelps look like a bobbing cork in the water; a cheetah would cross the finish line before Usain Bolt could reach the halfway point. Yet, we excel at inventing new ways to move, with or without tools. No animal comes close to exploring movement so richly; they simply move the way they are supposed to - always. Our movements constitute what Alexander Luria calls kinetic melodies: «inscribed in our bodies» as «dynamic patterns of movement» they "constitute that basic, vast, and potentially ever-expandable repertoire of 'I cans' [...] permeating human life» (Sheets-Johnstone, 2009: 255). In other words, 
such kinetic melodies articulate the kinds of patternings and dynamics we engage in our motile endeavors (Sheets-Johnstone, 2009: 331-22; 341-42). These dynamics are further enriched via novel developments driven, as we see in the next section, by rule-governed constraints.

Sports prominently expand our motile possibilities to compose symphonic kinetic melodies. In track and field, bipedal locomotion has been transformed into multifarious unique gaits and rhythms with specific kinesthetic harmonies. Consider for example the explosive bounciness of short sprints, the syncopated stride of marathoners, the elasticity of high jumpers, and the percussive steps of long jumpers. Moreover, sport's tool cornucopia -each implement requires special skills- astoundingly expands our repertoire of movements and experiential qualities. Each sport and utensil provides specific kinetic, and kinesthetic-tactile dynamics. But, as Sheets-Johnstone (2011:510) points out these should not be confused with discrete sensations. The most apt level of description is in terms of kinetic, kinesthetic and tactile dynamics. It bears pointing out that such qualitatively rich dynamics and experiences correlate positively with our skills: the more skillful we are, the richer the register with which we can compose our kinetic melodies.

To dive into these tactile, kinesthetic, and kinetic qualities we can rely on Sheets-Johnstone's $(1966 ; 2009 ; 2015)$ phenomenological analysis of the four cardinal structures of movement. While she derives these from her phenomenological analysis of dance, they readily and illuminatingly adapt to sports. Freediving or diving in apnea (holding one's breath) is a suitable candidate to present these. As the freediver descends there is: 1) a tensional quality, the initial significant effort to sink is overcome once the diver becomes negatively buoyant - what freedivers call the «sink phase»to then reverse the process when leaving the depths, 2) the descent's linear quality, head-first on the way down, streamlined in orientation and bodily contour along the vertical path traveled, 3) an amplitudinal quality, particularly of the torso as pressure compresses volumes until the lungs are the size of an apple before expanding on the way back, and 4) a projectional quality, how the energy is released, explosively at first and at the return point and restrained or absent during the negatively buoyant sink phase. Additional kinesthetic and kinetic/tactile dynamics can include: those felt as glottis, epiglottis, and tongue are maneuvered to equalize the pressure on the tympanum and within the mask, and the corresponding dynamics in the ear canal; the very fluid nature of the aqueous environs and their temperature; the meditative peacefulness of the sink phase' or 
the painful, unavoidable, and anticipated convulsions when the diaphragm contracts starving for oxygen. Moreover, an emotional tonality, which can range from extreme calm to anxiety or even panic, permeates the whole process we call 'a dive' - and which also extends to crucial moments before and after the actual time beneath the surface of the water.

Each sport has unique kinetic, kinesthetic and tactile dynamics, but structurally they all fit this four-tired model. Nonetheless, it is possible to carry out alternative phenomenological analyses that complement and enrich this one, thereby capturing other common elements within the plurality and uniqueness of sports. For instance, Gunnar Breivik (2011), using his own sporting experiences, has conducted phenomenological analyses of skydiving, kayaking, and mountain climbing, applying five phenomenological variables to each sport - body posture, skill, spatiality, temporality, and decision-making - to show the particular experiential lifeworlds they afford. In addition to enhancing purely performative possibilities and expanding our experiential catalogue, sports may lead to gnostic epiphanies. Thereby, they enhance our existential opportunities, the second qualitative facet aforementioned to which we now turn.

\section{THE EXISTENTIALLY VITAL FACET OF SPORT}

On a deeper level, further radicalizing its importance for life, sport proves to be more existentially vital than work and our eminently practical occupations and goals. Ortega's inveterate optimism contrasts with fellow phenomenologists Sartre's and Heidegger's darker musings. For him, the essence of our lives lies in our occupations (Ortega, 2006b), which eventually - due to life's needs - center on being productive by technologically adapting the environment to our needs (2006a). Technological efficiency raises the issue of how to spend our free time. Ortega presents two basic ways to live, one utilitarian and the other sportive, each tied to a lifeworld he calls 'landscape' (paisaje) (2004d). Each displays its own attitude to life. The former, focused on results and ends, tends to instrumentalize activities: ends prevail over means. We can argue that this is a mistake because it outsources the meaning of the activity itself to the terminus, forsaking the value of the process. For all its practical advantages, this ethos entails a narrow vital horizon for the Iberian (Ortega, 2004d: 426). The latter, the sportive ethos, exerts its energy superfluously, generously, without reserva- 
tions (2004d). Persons endowed with this sportive character embrace risk resolutely even if their devoted efforts may come to naught.

Indeed, ant to retake a theme from the opening section, risk is a prerequisite to enjoy a modicum of freedom. Sheets-Johnstone explains, «Where there is no felt risk, there is no personal involvement, and where there is no personal involvement there is no freedom» (2011: 292). Certain risk activities, when freely embraced, show precisely this courting of risk where existential insight is ripe for the taking. A phenomenological analysis of the running of the bulls (encierro) shows what is common to such risky experiences structurally (Ilundáin-Agurruza 2008a). ${ }^{2}$ One key aspect is the interplay of death and joy and the corresponding emotional attunement. In this context, Heidegger's and Sartre's respective views on death allow to examine the anticipation of death and help modulate our attitude toward such possibility. More positively, if we consider Nietzsche's philosophy, the encierro becomes a transformative event where the mundane becomes extraordinary as the inherent Dionysian exuberance is ritualized and formalized. But, most appositely, it is with Ortega that we can argue for how the very risking of life ultimately turns out to be the strongest affirmation of its importance and embodiment of its enjoyment. Willingly, we risk our life, our most precious "possession", for nothing. This voluntary expenditure of energy, even endangering of life, is the Orteguian ethos of the warrior of whom the sportsman is the heir, José Luis Molinuevo (2002) explains.

This ethos, radically sportive at heart, embraces challenges that demand suffering and discipline. It also values activities non-instrumentally, for what they are, favoring process over result without disposing of the latter. Inimitable, Ortega compares the impulse a billiard ball receives when hit by another, where there is equivalence of cause and effect, with the out of proportion reaction of a horse ever so lightly spurred, which obeys no outer impulse but the «release of exuberant inner energies» (2004f: 709, author's translation). The opening epigraph speaks to this. These enthused, inspiring exertions are vital to a flourishing life where its ebullient overflow brings creative undertakings. In this way, life grows out of spontaneous and energetic expressions and explorations. Ortega writes of how a paramecium's useful movements are chosen from myriad exploratory ones fruit of an ir-

2 For Spaniards, the encierro is not a sport, but, as an activity where one risks life and limb through a performance of athletic characteristics, it shares a common phenomenological structure to other risk activities. This analysis is based on Ilundáin-Agurruza's experiences, acquired during a six-year period when he ran the encierro in his native Pamplona. 
repressible vitality (Ortega 2007b). This vitality is sportive in character in just the way captured by this analysis. Much as Johan Huizinga claims of play (1955), Ortega remarks that culture is the daughter not of work but sport (2004d: 427), as are scientific endeavors, art, and morality (2004c). Those endeavors that matter most are but games where the most important thing is that we play them as well as we possibly can (Ortega, 2004e: 469). But, before excitedly jumping ahead this exuberance needs to be bridled.

This restrain arises from normative facets resulting from the interplay between limitations imposed by sport's formal structure and our species' morphokinetic limitations. In other words, the normativity derives from the rule-prescribed restrictions that limit efficient means in sports, and the constraints to our movement because of the kind of bodies we are. Yet, where there are constraints there are affordances, as J. J. Gibson (1979) argues - something to be explored momentarily. In fact, for Sheets-Johnstone play is marked by a spontaneity of movement where, «the sheer exuberance of movement dominates and in which a certain freedom of movement obtains» (2009: 323). Play, as primeval and spontaneous ludic activity, is common to humans and other animals. But games, when viewed as formalized activities defined by explicit rules, are a human affair. Characteristic of both, games and sports, are the rules that prescribe inexpedient means of achieving an activity's goal. Ortega was the first to adumbrate this view, as David Inglis points out (2004). Bernard Suits, independently, developed this into an alternative formalist analysis of games and a utopian view of life (1990). ${ }^{3}$ Accordingly, we use no hands in soccer or feet in basketball to handle the ball when it would be more efficient to do so. The repertoire of possible movements, as defined by rules devised around our psychophysical capabilities, ${ }^{4}$ sets what is to count not only as permissible, as Suits would consider, but in our view, as excellent. Put otherwise, normative facets are already built into the very metaphysical structure of sport.

Tethered to the previous existential analysis, this inefficiency means expending surplus energy gratuitously. This formal restriction creates nor-

3 In contemporary sport philosophy the rejoinder to Suits' formalism, which ignores cultural context and community of practitioners, is broad internalism. It centers on the internal goods that characterize a practice. For positive accounts of internalism see J.R. Russell (2007) and R. Simon (2007). W. Morgan (2012), based on a reigning ethos of deep conventions, offers a critique of internalism from the stance of conventionalism. FJ. López Frías (2014) further advances the debate by providing a refined hermeneutical critique of Morgan.

4 Here 'psychophysical' adjectively describes the activities our capabilities make possible. It is not a claim concerning metaphysical status. This seeks to avoid the fallacious dualistic divide between the mental and the physical. Our kinetic intelligence is an amalgamated bodymind, see Ilundaín-Agurruza (2014a; 2014b). 
mative, experiential, and creative spaces within a given environment - ludic affordances. By further restricting the types of movements and actions possible in a given context, rules create realms of excellence and creativity. They force participants to imaginatively solve athletic, martial, or aesthetic problems that rules and game pose. In the best cases, this leads to a sweet tension between challenge and abilities, as Kretchmar (1972) theorizes. Richard Fosbury's revolutionary high-jump technique creatively accomplished this. Paradoxically, inefficiency - elsewhere connected with lack of skill - becomes actually the precondition for skillful performances (when rule-limited and willingly embraced). Finally, risk - integral to this process as we always risk failure in sporting tests and contests - opens the door to meaningful spontaneity, exploratory opportunities, and normative assessments of our performances.

Where sport - particularly competitive but also recreational - differs from games is in its willing and disciplined cultivation of suffering, effort, and risk through ascetic, habit-developing training. Ortega's writings amply support this analysis (200f; 2007b). This askesis of disciplined movement markedly shapes sportspeople's bodies (Ilundáin-Agurruza, 2008b), gives sport its deeper significance, and leads to refined abilities. The highest exponent is the athlete in top form, whose absolute devotion means that she never lets herself go in anything for any reason, as Ortega explains (2005b). Moreover, while for the utilitarian ethos results are fundamental, something rampant in today's sportsworld, in a true sportive sense what really matters is the quality of the effort. It is not about quantification either - ubiquitous in high-performance sport, mad about all sorts of physiological parameters and statistical analyses. Countering this, Ortega specifies that what is valuable is the "tone, its perfection, its gentle impetus» (2007b: 832-833, author's translation). Behind all this lies a social background within and through which we learn to develop our skills and capacities. It is a communitarian lifeworld that shapes the sportsperson.

\section{THE SPORTIVE LIFEWORLD}

Standards of excellence and methods that the community in which a given practice takes place guide the development of sportive skills. This follows Alasdair MacIntyre (1984) views on virtue theory. ${ }^{5}$ Such communi-

5 Ilundáin-Agurruza \& Kuleli (2012) offer an application and critique of McIntyre's apparatus within the context of Turkish soccer. 
ties ultimately constitute sportive lifeworlds. A lifeworld which, as mentioned, Ortega theorized under the rubric of a landscape (paisaje). This is an environment that is not the world, but «only that group of objects or portions of this world that exist in a vital way for the animal» (Ortega 200d: 425, author's translation). For Ortega, this landscape is species specific and entails a mutual adaptation of human or animal to landscape/environment and vice versa. Here, the Spaniard follows the ideas of Jacob von Uexküll (2010) regarding the $u m w e l t$ (Ortega, 200d: 422-423; 2005a) (we return to this theme below). ${ }^{6}$ In our case, community and practitioners resonate intersubjectively: subjective kinetic/kinesthetic/tactile sporting experiences are shared, validated, and in the best cases, refined communally. The skiing community and its stewards help develop and share standards, techniques, technology, and provide a context wherein skiers interweave meaningful (inter)personal narratives.

Much of this complex process is shared through and embodied in our moving bodyminds. Sheets-Johnstone helps clarify, «Intersubjectivity is first and foremost an intercorporeality; it has to do with meanings engendered and/or articulated by living bodies» (McLaughlin \& Torres, 2011:274). ${ }^{7}$ Flourishing is tied to a cooperative spirit and shared body of knowledge and values. This also means sharing intersubjective bodily resonances. Driving the point home Sheets-Johnstone explains that, «corporeal and kinetic intentionalities and patternings develop on the basis of kinetic motivations into a kinetic repertoire that is at once both personal and social» (2009: 344). These repertoires blossom when both individual and community give themselves to the higher calling of their practice. In pursuit of excellence, the practice thrives. This requires a selfless giving on the part of all those involved. We can conceptualize this as a mutually caring attitude of attendance: an active devotion of aesthetic temperament with a willingness to serve (Ilundáin-Agurruza 2000; 2014b). The paradoxical outcome is not unlike the Christian notion of kenosis - the more they give themselves the more they receive without seeking it.

It is in the company of others that we are both challenged and supported in striving to be the best we can be. But because the community also provides hermeneutic tools to describe and interpret the pertinent experiences, an implication of moment is that lifeworlds enhance the ex-

6 Ortega (2007a) delineates the lifeworld/landscape especially in chapter 1, «Introducción sobre lo que es un paisaje» [Introduction on what a landscape is]. For a parallel use of von Uexküll's ideas see Sheets-Johnstone (2009: 139, 172, 286).

7 The original citation is found in Sheets-Johnstone (1994: 54). 
perience and signification of practices uniquely, even when overtly engaged in putatively analogous practices. An East-West contrast proves pertinent.

Japanese $d \bar{o}$, arts of self-cultivation, are particularly appropriate. Integrating theory and praxis, they are contemplative and active paths toward excellence. Two such paths are kendo (the way of the sword,剣道) and kyudō (the way of the bow, 弓道). Sports and $d \bar{o}$ may be formally similar since both restrict movement and are rule governed, but they are also markedly different cultural endeavors. Yet, studying them together shows how other ways of performative and disciplined movement offer alternative values that may be complementary to or even ameliorative of those in sports (considering the ills in contemporary sports).

To begin, from analogous kinetic/kinesthetic dynamics, we obtain very different performative and phenomenological outcomes. For example, the putative equivalence between sports' flow performance states and martial arts' mushin (無心) states is not warranted phenomenologically on account of the latter's Buddhist underlying framework (Krein and IlundáinAgurruza, 2014). Moreover, regarding human abilities and performances, Western views center on normality and «average» performers, stressing physical effort, training, tactics, and results (these are called keiko in Japanese, 稽古). However, Japan favors exemplary individuals who excel and embrace shugyō: the endeavor to excel in a lifelong commitment (Carter, 2008). Emphasizing process and reflection, this lifelong striving becomes truly educational and Orteguian in its aspiration to bring out the best in us. This distinction between keiko and shugyo (修行) already shows a specific and distinct categorical conceptualization of said processes. Embedded in traditional $d \bar{o}$, shugyo objectively and performatively grounds excellence.Archery in the West and kyudō illustrate and help explain this.

Both have similar morphokinetic and formal constraints: they require pulling the string attached to the bow while holding the arrow in position until it is released (in archery, however, one pulls as the bow is raised, whereas in kyudo the pulling happens when lowering the bow). But, because they emphasize different aspects of what the actual target is and how to do it, they diverge greatly in significance and qualitative dynamics. Archery focuses on target acquisition while kyudō stresses form, release of the arrow, and exploration of the why of shooting. ${ }^{8}$ It is a way to forge the kyudōka's (弓道家) spirit and character (Acker, 1998). Archery is done in-

8 Herrigel's account (1999) of his experiences with Kyud are informative if at times somewhat suspect form a purist stance as to their accuracy concerning Zen Buddhism. 
dependent of gnostic aspects. We may well learn truths about ourselves, but from a sporting sense this is incidental. Fundamentally, it is about hitting the bull's eye. $k y u d \bar{o}$ cares not a whit if all the arrows miss. Obviously, kyudo practitioners do aim at the target. But, it is in itself valueless as target. Rather, aiming at and hitting the target acts only as overt confirmation that the process as transformative practice is working. Critically, this offsets the West's goal-oriented, instrumentalizing focus that sometimes results in unvirtuous action (e.g., cheating).

The Japanese lifeworld and practices build into these transformative activities meditative techniques, Buddhist tenets, and phenomenological methods. In kindred spirit, John Cogan (2006) asserts with regard to Husserl's methodology that a veritable phenomenological practice seeks to transform our perspective of the world and ourselves. This allows practitioners to better describe and discriminate their experiences and, ceteris paribus, results in a richer lifeworld. In this sense, $d \bar{o}$ are poised to help their practitioners thrive holistically.

Discipline may turn conscious activity and deliberation into a heuristic and spontaneous mastery of actions, intentions, and emotions when honed over years of careful self-examining practice. Then our skillful actions become both process and goal. This takes place through an integrated bodymind (Yuasa 1987). These movements become part of our repertoire of kinetic ways of self-expression. Such an inventory is personal and social, unique and shared, as we have just discussed with Ortega and SheetsJohnstone. It is individual and distinctive in so far as our specific morphological characteristics imprint our particular way of moving about the world. Much as our handwriting, our gait is all our own, and our friends can recognize us by the way we walk for example. It is shared in so far as our society also gives us patterns of motility. To delve further, the work of anthropologist Marcel Mauss (1950) is enlightening.

Mauss' Les Techniques du Corps (The Techniques of the Body) greatly influenced Michel Foucault's (1988) ideas on the care of the self and Bourdieu's (1984) understanding of the habitus. For Mauss, in a sort of rapprochement to Eastern ways of the bodymind, the complete person, ' 1 'homme total,' is psychosocial and physiological (1950). Moreover, Mauss highlights how we imbibe our corporeal manners from the surrounding society, from the way we walk or dance, to the way we swim, or move our hands whether eating at the table or speaking. While our personality imprints these, our movements also reflect strongly whence we come. In fact, and very interestingly, the variations are not as much personal as social 
(Mauss 1950). Yoshinori Kono, the most famous Japanese sensei of traditional martial arts (kory $\bar{u}$, 古流, rather than kakutogi, combat sports, 格闘 技), speaks to this. He asserts, when comparing the old ways with the new ones, how in olden times instruction brought deep changes in the pupils' ways of using their bodies (Tamaki, 2010). For instance, samurai walked in an idiosyncratic fashion, with a low center of gravity and spread legs, thus stable and at the ready. These corporeal techniques give norms, normal patterns, that societies, and within these, groups of people and then individuals, incorporate as ways of moving about in the world. But even among those who share such ways and movements, there are those who are exceptional and, at times, shape them.Those who truly excel in such lifelong pursuits can become not just role models, as may be the case with outstanding athletes, but moral and performative exemplars. Leading by example, they demonstrate a superior way of life.

\section{EXEMPLARS AND SKILLFUL FLUENCY}

In the West, most research has focused traditionally on the normal to establish the baseline, and then on the pathological as a way to find sufficient theoretical and empirical contrast with which to better understand and validate the parameters of that normality. Thus, there are very good reasons for current research in cognitive, neuroscientific and phenomenological studies to investigate the pathological and the normal (Gallagher 2005). . Gallagher and Zahavi argue that, «Pathological cases can function heuristically to make manifest what is normally or simply taken for granted» in order to gain distance from the familiar, something their detailed analysis of pathologies of the self-concerning our awareness of agency and ownership clearly shows (2008: 140). But, among other reasons, a full understanding of animate and disciplined movement cannot ignore those accomplished individuals who are superb performers and inspiring paragons (Ilundáin-Agurruza, 2014b). Extant literature on athletic excellence, pace Dreyfus (2014), speaks of "skillful coping» when discussing these superior performances. While it makes sense to speak of coping when referring to the struggles most of us undergo striving to perform well, the present proposal is a new coinage to mark the difference between para-

9 In his insightful analysis of pathology, Shaun Gallagher (2005) examines lack of proprioception and its consequences, prenoetic aspects not reducible to neurophysiology, and the consequences of schizophrenia. 
gons and the rest: skillful fluency. Derived from the Latin fluere, to flow, 'fluency' means gracefulness and ease of movement or style. While all of us have a somatic style to our movement, in sports and other performative activities this skillful fluency becomes a kinetic signature. As a signature, through the practice of patterned movements, becomes uniquely ours and is not simply our name in our handwriting, so does a corporeal kinetic signature imbue masters' movements with a recognizable quality all their own. Skillfully fluent and extraordinary performers push the very possibilities of movement. They test our assumptions about what we may achieve as humans in terms of both performance and life-possibilities. Kinetically fluent sportspeople do not cope but excel-elegant even in their suffering. Along the way, they sometimes correct scientists and may even expand our existential horizons.

For instance, and to return to the fluid world of freediving, four decades ago, physicians and physiologists set a 50-meter (165 ft.) limit beyond which, they prognosticated, death by compressed viscera would ensue (Pelizzari and Tovaglieri, 2004). Today divers William Trubridge and Herbert Nitsch, through a refinement of diving techniques, skills, meditative practices, and improved safety protocols - all part of that communitarian «landscape» - have respectively reached 101 meters (333 ft.) without fins or weights, and 214 meters ( $807 \mathrm{ft}$.) with an underwater sled. In the 1960's Enzo Maiorca and Jacques Mayol were the first to venture into aqua incognita and, through their mutual contest, push past the limit of 50 meters. In doing this, they explored human physiological responses beyond known parameters. Concurrently, and more importantly, confronting their mortality they also expanded the existential contours of their values: they were willing to risk death to develop themselves and the practice. Besides correcting scientific dogma, which has led to new research possibilities as the scientists labor to explain such performances or the mammalian dive reflex in humans, this has also stimulated and opened existential ways and performative depths for the rest of us. Nowadays, freedivers cross the 50meter mark as a matter of course.

Going deeper yet, the very best among experts also can become moral points of reference. This is clearest in the case of sense $i$ in martial arts, but some sportspeople have shown enviable moral qualities. Eugenio Monti, at the 1963 Inssbruck Winter Olympics, lent a crucial part to the British team, who were the eventual winners. Cléret and McNamee (2012) argue that these kind of acts show that competition is less about domination than 
about generating human excellence. Nonetheless, not everything is inspirational or exceptional in the world of superior performance.

Whereas paragons of excellence serve as performative paradigms and may be moral exemplars, what may be called 'a-paragons' stand out for the wrong reasons. The world of elite sport provides the clearest case. There are many cases of sportspeople who were role models, such as homerun record-breaker baseball players Sammy Sosa, Barry Bonds, and Jerry McGwire; some were even seen as morally exemplary, e.g., cyclist Lance Armstrong and his exploits on the bicycle and support of cancer victims. For different reasons that wrongly instrumentalize sports, using the sporting process primarily as a means to obtain extrinsic rewards such as money or fame, they all cheated. Thus, here the nominally 'superior' performance is not only a mirage of excellence, but it is also decoupled from a superior moral status. Moreover, cheats will never know their true athletic worth, as Reid (2010) argues using her own experiences as an elite bicycle racer, precisely because the way they compete precludes them from measuring themselves against others in the same conditions. Were sports to return to their roots, valuing their very superfluity, embracing a more explicit focus on cultivation of process and character, in the way of traditional $d \bar{o}$, we would find less "fallen angels» and more true exemplars.

To switch now from the normative side to the performative one, and contrary to common assumptions by academics and public alike, superior performances are neither effortless nor mindless. The state of mushin, often mistranslated as 'no-mind,' is that of a holistic bodymind where the psychophysical processes are integrated and function fluently. ${ }^{10}$ Hence, instead of mindlessness there is extreme concentration without distraction. The idea is that the mind is supposed to be unstoppable, in the sense that it is immovable, that is, unmoving, Takuan Soho (1987) explains to famed samurai Yagy $\bar{u}$ Munenori. The outcome is that skillfully fluent individuals achieve a greater unity and integration of bodily and mindful processes. This state requires constant practice.

Intraspecies abilities fall within a continuum that is dynamic not only across individuals but for a given individual, as his or her form peaks and wanes. The adage «use it lose it» holds true for all, no matter how talented. Skillful fluency involves habits, dedication, and discipline that few are will-

10 Shigenori Nagatomo (1992a and 1992b) and Yasuo Yuasa (1987) each have developed views that argue for a view of a bodymind wherein individuals' achievement of integrative and organic unity is an epistemological and practical issue (developed through meditative and active practices) rather than an ontological one. After independently developing a similar analysis, the author encountered their writings and saw the happy congruence of viewpoints. 
ing or able to endure. The countless miles that elite runners run, or the innumerable laps of Olympic-caliber swimmers speak to this. Musashi Miyamoto, arguably the foremost swordsman in Japan's history, writes, in the seventeenth century, about one thousand days of training to develop and ten thousand days of discipline to polish oneself (Tokitsu 2004). Following and popularizing the ideas of sport psychologist K.Anders Ericsson (2003), Malcolm Gladwell (2008) echoes the idea that excellence requires ten years and 10,000 hours of deliberate practice. This pales, however, with Musashi's numbers, which amount to 30 years of eight-hour days. Another historical example sows the ground for the last section and gives a concrete idea of the kind of requisite dedication. Iai (居合) or iaidō (居合道) is the fast and fluid drawing of a katana. In Hayahizaki temple there are records of $i a i$ masters drawing the sword thirty or forty thousand times over several days, while the top three, drew it over ninety thousand times in a week (Tokitsu, 2004: 290). Their objective was to surpass their limits while cultivating the sort of fluency under consideration to achieve bodymind integration.

\section{PHENOMENOLOGY, HISTORY, AND OUR SHARED SKILLFUL STRIVINGS TO EXCEL}

The previous historical references allow for a suitable transition into the historical facet of phenomenology. Besides showing how we think in movement, i.e., as animate bodyminds, a suitably adapted phenomenology can also describe and open our eyes to broader intersubjective phenomena that surround us in mutually influential ways. Husserl's latter work on generative phenomenology and Ortega's historical reason, both influenced by Dilthey, are pertinent now. Steinbock's (1995) landmark work shows that there was an evolution in Husserl's thinking from a static phenomenology centered on a transcendental analysis of the ego, to a genetic one that is dynamic and intersubjective, and then to a generative one that describes our process of becoming and the influence of generations in our lives. Specifically, it considers geo-historical aspects where history, geography, even climate are of import, in addition to other cultural and normative aspects. Husserl posits a homeworld that is normatively significant in relation to an alienworld. For example, in Japanese medieval times we have the homeworld of the Imperial Palace in Kyoto as opposed to the alienworld 
of the surrounding forests in Mt. Kurama, the lair of mythical tengu, swordwielding demons (天狗).

To delve more into the interface between history, geography, and a form of life, we can consider the time comprised between the Muromachi Period (1338-1573) and the Azuchi Momoyama Period (1573-1867). This timeframe incorporates deep changes in the martial Japanese structure and way of life, which transformed from bujutsu, warfare techniques (武 術), to budō (武道), martial way, and saw the code of bushidō (武士道) become codified and refined. These changes were more significant in Japan than elsewhere because of the much larger portion of the population that belonged to the warrior class.As Noel Perrin points out, at comparable times in Europe nowhere did the warrior class population exceed 1\%: in England we find about sixty lords, five hundred knights, and 5,800 squires and gentlemen (1979: 35). Japan in 1597 had an astounding two million people who belonged to this class, about $8 \%$ of the total Japanese population (Perrin 1979: 33). This is significant no only because of the (comparatively) sheer size of the class, but above all because of its influence: it had disproportionate political and social clout given that the power rested in the hands of the daimy $\bar{o}$, feudal lords, and their armies rather than with the Imperial Family. The homeworld was thus defined by the mores and ways of a warrior culture where the very geography of Japan, whose mountains and valleys led to many fiefdoms, its warring past, and the alliance between Zen and the samurai, imbued life all around with a martial quality that thickly permeated Japanese life everywhere.

To evoke Mauss' ideas, this could be seen not only in the way people walked but also their hairstyles (even commoners often shaved their heads, which originally was done for the purpose of wearing a kabuto or battle helmet). Likewise, even the high sense of honor and service manifested underlying tensions between duty to one's superiors (giri, 義理)) and an individual's conscience (ninjō, 人情), that were modulated by etiquette cues with very specific movements. This homeworld does not specify what is average but typical and best in terms of aesthetic and existential concerns. It gives us our world. In this case, a world of martial arts that evolves such that, through bushidō, people practice a way of self-cultivation by means of habit and mindful practice that may achieve bodymind integration and probity.

Ortega's work also reflects this. He phenomenologizes the relevance of the landscape as a crucial element of how we become who we are.Already in 1914, in his "pedagogy of the landscape,» we see how we are shaped in 
significantly constitutive ways by the land we inhabit, its weather, the rocks, trees, water and the rest, which also shape one another (Ortega, 2004c: 99-103). Just as important the historical plays an ontologically vital role in his oeuvre. As he famously said, «Man, in a word, has no nature; what he has is-history. Expressed differently: what nature is to things, history, res gestae, is to man» (Ortega, 1961:217). Our history and our historical conditions, what Ortega called our circumstances, the things that surround us (to include landscape, objects, and events) also constitute our radical reality, our radical life.

Unable to indulge in a thorough comparison that promises to be tantalizing, it is worth noting the evocative resonances between Husserl's and Ortega's ideas and those of Watsuji Tetsurō (1996) and his ethics of «in betweeness of human beings», ningen, in the Japanese vernacular (originally jinkan in Buddhism; both use the same kanji,人間). For Watsuji a human being (versus an animal) must be a dialectical unity between individual and member of society (1996:14-15). We are defined $i n$ our relations with others. This takes place through a subjective spatiality, the essential characteristic of human beings, which arises from "the manner in which multiple subjects are related to one another» (Watsuji, 1996:157). For him this spatiality also includes the factor of climate and culture, which binds us together as a people (Watsuji, 1961). He writes, «But as we have been able to use the expression «we feel the cold» without any difficulty, it is «we» who experience the cold, not «I» alone» (Watsuji, 2011: 858). In all of these, the dynamics that pertain to sport, from kinesthetic/kinetic/tactile to social and environmental ones richly and complexly intertwine in ways that are both common and unique.

Phenomenology reveals that there are certain invariants that structure these exceptional performances and experiences, notably the aforementioned fluency. These performances are not accidental; such superb performers regularly operate at extraordinary levels. However, the perspective afforded by a generative and historically sensitive phenomenology shows that the ways such paragons reach their level of excellence is structured by these very geo-historical and cultural circumstances. They become exceptional through their talent and endowments, but they are part of wider communities, be these martial, sportive, academic, religious, scientific, or artistic. 


\section{CONCLUDING REMARKS}

Of course, few are gifted enough to become such paragons. But that is no reason not to try to fulfill our personal excellence. For Ortega each person must be measured against herself, her own ideal of perfection, not an outside standard (2004a). From this sportive way of life, and predating Husserl's own normative turn, ${ }^{11}$ Ortega derives a normative ideal where the underlying essence of sport, predicated on bridled enthusiasm, demands this personal perfection from us. This he often expressed by citing Pindar, «learn and become who you are» - in contrast to common mores and moral propriety of doing the required minimum (Ortega, 2004a: 181; 2005a, 488; 2008a: 150; 2008b: 285; 2008c: 511). As samurai Yamamoto Tsunetomo stated, «Throughout your life advance daily, becoming more skillful than yesterday, more skillful than today.This is never ending» (1979: 27). Truly, we are at our best when engaged in perennial skillful strivings.

\section{REFERENCES}

ACKer, W. R. B. (1998): Kyudo: The Japanese Art of Archery, Boston, Rutland (vT), Tokyo, Charles Tuttle Co., Inc.

BEYER, C. (2011): «Edmund Husserl», Stanford Encyclopedia of Philosophy, ZalTA, E. N. (ed.), http://plato.stanford.edu/archives/sum2015/entries/ husserl/

Bordieu, P. (1984): Distinction: A Social Critique of the Judgment of Taste, London and New York, Routledge.

Breivik, G. (2011): «Dangerous Play with the Elements:Towards a phenomenology of Risk Sports», Sports, Ethics and Philosopby, 5(3), pp. 314330.

CARTER, R. E. (2008): The Japanese arts and self-cultivation, Albany, State University of New York Press.

Cléret, L. and Mcnamee, M. (2012): «Olympism, the Values of Sport, and the Will to Power: de Coubertin and Nietzsche Meet Eugenio Monti», Sport, Ethics and Philosopby, 6:2, pp. 183-194.

11 As Christian Beyer points out, Husserl, «formulates a «categorical imperative» that makes recourse to the notion of lifeworld, or environment, as follows: Always act in such a way that your action contributes as well as possible to the best (the most valuable) you recognize yourself to be able to achieve in your life, given your individual abilities and environment (cf. Husserliana, vol. XXXVII, pp. 251 ff.)" (2011: 27). Ortega embraced Husserl's phenomenology as early as 1914, if not uncritically (see Ortega, 2004a). 
Cogan, J. (2006): "The Phenomenological Reduction», Internet Encyclopedia of Philosophy, http://www.iep.utm.edu/phen-red/

Dewey, J. (1980): Art as Experience, New York, Perigee Books.

Dreyfus, H.L. (2014): Skillful Coping: Essays on the Phenomenology of Everyday Perception and Action, Wrathall, M (ed.) (2014), Oxford, Oxford University Press.

Ericsson, K .A. (2003): «Development of Elite Performance and Deliberate Practice: An Update from the Perspective of the Expert Performance Approach", in Expert Performance in Sports: Advances in Research in Sport Expertise. STARKe J \& ERICcson A. K. (eds.), Champaign, Human Kinetics, pp. 49-83.

Foucault, M. (1988): The Care of the Self, New York, Vintage Books.

Gallagher, S. (2005): How the Body Shapes the Mind, Oxford \& New York, Oxford University Press.

Gallagher, S. \& Zahavi, D. (2008): The Phenomenological Mind, Oxon UK \& New York, Routledge.

Gibson, J. J. (1979): The Ecological Approach to Visual Perception, Boston, Houghton-Mifflin.

Gladwell, M. (2008): Outliers: the story of Success, New York, Little, Brown, and Co.

Herrigel, E. (1999): Zen and the Art of Archery, New York, Vintage.

Huizinga, J. (1955): Homo Ludens: a study of the element of play in culture, Boston: Beacon Press.

ILUNDÁIn-AgurRuZA, J. (2000): ... In the realms of art: a conceptual inquiry of the genesis of the work of art.Thesis (Ph. D.), University of Illinois at Urbana-Champaign.

- (2008a): «Between the Horns. Part II: an existentialist solution to the dilemma on the running of the bulls», Sport, Etbics, and Philosophy, 2:1, pp. 18-38.

- (2008b). "Athletic Bodies and the Bodies of Athletes: A Critique of the Sporting Build», Proteus: A Journal of Ideas, 25:2, pp. 15-22.

- (2014a): "Skillful Striving: Holism and the Cultivation of Excellence in Sports and Performative Endeavors», Sport, Ethics and Philosophy, 8:3, pp. 221-342.

- (2014b): «Skillful Striving: Holism and the Cultivation of Excellence in Sports and Performative Endeavors», Sport, Etbics and Philosophy, 8:4, pp. 343-573. 
- (Forthcoming): «The Eye of the Hurricane: The eye of the hurricane: philosophical reflections on risky sports, self-knowledge and flourishing», Journal of the Philosophy of Sport.

ilundáin-Agurruza, J., Gagliardini, L. \& Jáuregui-Olaiz, J. A. (2012): «On the Crest of the Wave:The Sublime, Tempestuous, Graceful, and Existential Facets of Sailing», in Sailing-Philosophy for Everyone. Goold, P. (ed.) (2012), Chichester, Wiley Blackwell, pp. 109-121.

Ilundáin-AgurruZA, J. \& Kuleli, C. (2012): «A New Heart for Turkish Soccer: a MacIntyrean analysis of the beautiful game», Soccer in the Middle East. Soccer E Society, 13:5 \& 6, pp. 667-687.

InGLIS, D. (2004): «Meditations on Sport: On the Trail of Ortega y Gasset's Philosophy of Sportive Existence», Journal of the Philosophy of Sport, 31, 78-96.

Krein, K. \& Ilundáin-AgurruZA, J. (2014): «An East-West Comparative Analysis of Mushin and Flow», in Philosophy and the Martial Arts, PRIEST G. \& Young, D. (eds.) (2014), London, Routledge, pp. 148-169.

Kretchmar, S. (1972): «From test to contest: An analysis of two kinds of counterpoint in sport", Journal of the Philosophy of Sport, 2, pp. 2330.

López FríAs, F. J. (2014): «William J. Morgan's 'conventionalist internalism' approach. Furthering internalism? A critical hermeneutical response», Sport, Ethics and Philosophy, 8:2, pp. 157-171.

Macintyre, A. (1984): After Virtue: a Study in Moral Virtue. $2^{\text {nd }}$ ed. Notre Dame, Indiana, University of Notre Dame.

Mauss, M. (1950): «Les Techniques du Corps», in Sociologie et Anthropologie. Paris, Presses Universitaires de France, pp. 364-386.

Mclaughuin, D. \& Torres, C. (2011): «Sweet tension and its phenomenological description: sport, intersubjectivity, and horizon", Sport, Ethics and Philosophy, 5:3, pp. 270-284.

Molinuevo, J. L. (2002): Para leer a Ortega, Madrid, Alianza Editorial.

Morgan, W. J. (2012): «Broad Internalism, Deep Conventions, Moral Entrepreneurs", Journal of the Philosophy of Sport, 39:1, pp. 65-100.

Nagatomo, S. (1992a). Attunement Through the Body, Albany, suny Press.

- (1992b): «An Eastern Concept of the Body:Yuasa's Body-scheme», in Giving the Body Its Due. SheEts-Johnstone, M. (ed.) (1992), Albany, suny Press, pp. 48-68.

ORTEga y GASSET, J. (1961): History as a System and Other Essays Toward a Philosophy of History, Boston, W. W. Norton \& Company. 
- (2004a): «Sobre el concepto de sensación», Obras Completas, vol. I, Madrid, Taurus, pp. 624-638.

- (2004b): «Estética en el tranvía», Obras Completas, vol. I, Madrid, Taurus, pp. 176-182.

- (2004c): «Meditaciones del Quijote», Obras Completas, vol. I, Madrid, Taurus.99-103.

- (2004d): «El Quijote en la escuela», Obras Completas, vol. II, Madrid, Taurus, 401-430

- (2004e): «Carta a un joven argentino que estudia filosofía», Obras Completas, Vol. II, Madrid, Taurus, pp. 467-471.

- (2004f): «El Origen deportivo del estado», Obras Completas, vol. II, Madrid, Taurus, pp. 707-719.

- (2005a): «La magia del "debe ser"», Obras Completas, vol. III, Madrid, Taurus, pp. 486-488.

- (2005b): «Misión de la Universidad», Obras Completas, vol. IV, Madrid, Taurus, pp. 529-568.

- (2005c): «Temple para la reforma», Obras Completas, vol. IV, Madrid, Taurus, pp. 1034-41.

- (2006a): «Meditación de la técnica», Obras Completas, vol. V, Madrid, Taurus, pp. 561-605.

- (2006b): «Prólogo a veinte años de caza mayor», Obras Completas, vol. VI. Madrid, Taurus, pp. 269-333.

- (2007a) «Temas del Escorial», Obras Completas, vol. VII, Madrid, Taurus, pp. 405-421.

- (2007b): «El sentido deportivo de la vitalidad», Obras Completas, vol.VII, Madrid, Taurus, pp. 818-834.

- (2008a): «QQué es la ciencia, qué es la filosofía? [Lección III]», Obras completas, Vol. VIII, Madrid, Taurus, pp. 148-158.

- (2008b): «¿Qué es filosofía? Lección IV]», Obras completas, Vol. VIII, Madrid, Taurus, pp. 278-290.

- (2008c): «El hombre y su circunstancia», Obras completas, Vol. VIII, Madrid, Taurus, pp. 499-511.

Pelizzari, U. \& Tovaglieri, S. (2004): Manual of Freediving: Underwater on a single breath, Reddick, FL, Idelson Gnocchi.

PERrIN, N. (1979): Giving Up the Gun: Japan's Reversion to the Sword, 1543-1879, Jaffrey (NH), David R. Godine, Publisher, Inc.

REID, H. (2010): «My Life as a Two-Wheeled Philosopher» in IlundÁIn-AgurruZA, J \& Austin, M (eds.) (2010), Malden MA \& Oxford uk, Wiley-Blackwell, pp.151-161 
- (2009): «Sport, philosophy, and the quest for knowledge»,Journal of the Philosopby of Sport, 36:1, pp. 40-9.

Russell, J. (2007): «Broad internalism and the moral foundations of sport» in Ethics in Sport, $2^{\text {nd }}$ ed., Morgan, W. J. (ed.) (2007), Champaign-Urbana, Human Kinetics, pp. 51-66.

Sheets-Johstone, M. S. (1966): The Phenomenology of Dance. Madison and Milwaukee, University of Wisconsin Press.

- (1994): The Roots of Power:Animate Form and Gendered Bodies, Chicago and La Salle, Open Court.

- (2009): The Corporeal Turn: an interdisciplinary reader, Exeter, Imprint Academic.

- (2011): The Primacy of Movement, Expanded $2^{\text {nd }}$ ed., Amsterdam \& Philadelphia, John Benjamins Publishing Co.

- (2015) The Phenomenology of Dance, Fiftieth Anniversary Edition, Philadelphia, Temple University Press.

SIMON, R. (2007): Internalism and internal values in sport in Ethics in Sport, $2^{\text {nd }}$ ed., Morgan, W. J. (ed.) (2007), Champaign-Urbana, Human Kinetics, pp. 35-50.

Slocum, J. (1956): Sailing Alone Around the World, New York, Dover Publications.

STEInbock, A. J. (1995): Home and Beyond: Generative Phenomenology after Husserl, Evanston, IL, Northwestern University Press.

Suits, B. (1990): The grasshopper: Life, games and Utopia, Boston, MA, David R. Godine Publisher.

Takuan, S. (1987): The Unfettered Mind, Tokyo, Kodansha.

TAmaki, L. (2010): "Yoshinori Kono: Le Virtuouse du Bujutsu», Samourai 4 , pp. 12-18.

Tokitsu, K. (2004): Miyamoto Musashi: His Life and Writings, Boston, Shambhala.

Uexküll, J. V. (2010): A Foray into the Worlds of Animals and Humans: With A Theory of Meaning, Minneapolis, University of Minnesota Press.

Watsuj, T. (1961): Climate and Culture: a Pbilosopbical Study, Tokyo, Hokuseido Press.

- (1996): Watsuji Tetsurō's Rinrigaku: Etbics in Japan, Albany, State University of New York.

- (2011): "A Phenomenology of the Cold» in Japanese Philosopby:A Sourcebook, Heisig, J. W., Kasulis, T. \& Maraldo, J. (eds.) (2011), Honolulu, University of Hawai'i Press, pp. 858. 
72 RECERCA · DOI: http://dx.doi.org/10.6035/Recerca.2016.18.4 - ISSN: 1130-6149 - pp. 49-72

Yамамото, T. (1979): Hagakure, Tokyo, Kodansha International.

Yuasa, Y. (1987): The Body: Toward an Eastern Mind-Body Theory, Albany, SunY Press. 